\title{
Effect of Probucol on Proliferation of Leukemia, Multiple Myeloma, Lymphoma, and Fibroblast Cells
}

\author{
Probukolün Lösemi, Multipl Miyeloma, Lenfoma ve Fibroblast Hücre \\ Hatlarının Proliferasyonu Üzerindeki Etkileri
}

\author{
(D) Aslı KOÇ*, (D) Arzu Zeynep KARABAY, (D) Ali YAPRAK, (D) Zeliha BÜYÜKBiNGÖL, (D) Fügen AKTAN \\ Ankara Universtiy Faculty of Pharmacy, Department of Biochemistry, Ankara, Turkey
}

\begin{abstract}
Objectives: Probucol is a bisphenol antioxidant with antiinflammatory, antilipidemic and antidiabetic effect. Development and progression of cancer is closely related to chronic inflammation and oxidative stress. Agents that target these processes have been shown to modulate cancer cell proliferation. In this regard, the effect of probucol on proliferation of different cancer cell lines was investigated.

Materials and Methods: Different concentrations of probucol solutions were prepared and applied to the following cancer cell lines: K562S (imatinib sensitive) and K562R (imatinib resistant) chronic myeloid leukemia (CML) cells; U937 histiocytic lymphoma cells; HL60 acute myeloid leukemia cells; U266, H929, and RPMI8226 multiple myeloma cells; and L929 fibroblast cells. Cell viability was conducted by 3-(4,5-dimethylthiazol-2-yl)2,5-diphenyltetrazolium bromide assay.

Results: Significant toxicity was not exhibited due to probucol treatment (0.1-10 $\mu \mathrm{M})$ in K562S and K562R CML cells, U937 histiocytic lymphoma cells, HL60 acute myeloid leukemia cells, U266 multiple myeloma cells, and L929 fibroblast cells. However, probucol treatment significantly inhibited the viability of $\mathrm{H} 929$ and RPMI8226 multiple myeloma cells at the concentration of 0.5-10 $\mu \mathrm{M}$ and 5-10 $\mu \mathrm{M}$, respectively.

Conclusion: Probucol treatment slightly inhibited the viability of other cancer cell lines, but significantly inhibited the viability of H929 and RPMI8226 multiple myeloma cells. However, its effect was not potent, since a $50 \%$ reduction in cell viability could not be achieved at the concentrations of probucol treatment administered.
\end{abstract}

Key words: Probucol, chronic myeloid leukemia, multiple myeloma, histiocytic lymphoma, acute myeloid leukemia

öz

Amaç: Probukol, antiinflamatuvar, antilipidemik ve antidiyabetik aktivitelere sahip bisfenol bir antioksidandır. Kanser gelişimi ve ilerlemesi kronik inflamasyon ve oksidatif stres ile yakından ilişkilidir ve bu süreçleri hedefleyen ajanların kanser hücre proliferasyonunu modüle ettikleri gösterilmiştir. Bu bağlamda, bu çalışmada, probukolün farklı kanser hücre hatlarının proliferasyonu üzerindeki etkileri araştırılmıştır.

Gereç ve Yöntemler: Probukolün farklı konsantrasyonlarda hazırlanan çözeltileri kullanılarak K562S (imatinib duyarılı), K562R (imatinib dirençli) kronik miyeloid lösemi (KML), U937 histiositik lenfoma, HL60 akut miyeloid lösemi, U266 multipl miyeloma ve L929 fibroblast hücre hatlarında hücre canlılığı 3-(4,5-dimethylthiazol-2-yl)-2,5-diphenyltetrazolium testi ile belirlenmiștir.

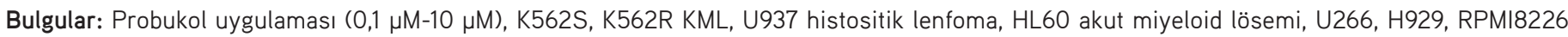
multipl miyelom ve L929 fibroblast hücre hatlarında anlamlı bir etki göstermemiștir. Diğer taraftan, probukol uygulaması, H929 ve RPMI8226 hücre serilerinin canlılı̆̆ını sırasıyla 0,5-10 $\mu \mathrm{M}$ and 5-10 $\mu \mathrm{M}$ konsantrasyon aralığında anlamlı olarak azaltmıştır $(p<0,05)$.

Sonuç: Probukol uygulaması H929 ve RPMI8226 multipl miyelom hücre hatlarının canlılığını anlamlı olarak inhibe etmiştir. Fakat, probukolün bu etkisi potent bulunmamıștır ve uygulanan konsantrasyon aralığında, hücre canlılığında \%50 ve üzerinde azalma sergilemediği belirlenmiștir.

Anahtar kelimeler: Probukol, kronik miyeloid lösemi, multipl miyelom, histositik lenfoma, akut miyeloid lösemi

*Correspondence: aslikoc79@gmail.com, Phone: +90 50540320 96ORCID-ID: orcid.org/0000-0002-4679-9079

Received: 25.10.2019, Accepted: 16.12.2019

-Turk J Pharm Sci, Published by Galenos Publishing House. 


\section{INTRODUCTION}

Probucol is a bisphenol, which was originally synthesised as an antioxidant compound with antilipidemic effect.1.2 Probucol has been shown to inhibit the oxidation of low density lipoprotein (LDL) and lower the level of cholesterol in the bloodstream by increasing the rate of catabolism of LDL. ${ }^{3}$ Although probucol has been used extensively as a lipid-lowering drug in Japan, its reducing effect on serum high density lipoprotein cholesterol has posed a major setback, thus limiting its use in western countries. ${ }^{4}$ Nevertheless, the effect of probucol is currently being reexamined, as various studies aim to elucidate its pleiotropic functions and effects. According to these studies, probucol has been shown to inhibit neurovascular inflammation as a single agent, ${ }^{5}$ inhibit atherosclerosis when combined with atorvastatin, ${ }^{6}$ exert beneficial effects on cognitive functions ${ }^{7}$ and exhibit neuroprotective effect in animal models of Parkinson's ${ }^{8}$ and Huntington's disease. ${ }^{9}$ In addition, probucol has been demonstrated to inhibit inflammation due to its antiinflammatory effect in beta cells,,$^{10}$ as well as its inhibitory activity on nuclear Factor kappa B (NF-KB) in spinal cord inflammation."

Oxidative stress and chronic inflammation are among the characteristic features of neoplastic diseases. Overproduction of reactive oxygen species within the cell plays a major role in signaling pathways, leading to the initiation and progression of cancer and possible drug resistance. ${ }^{12}$ In contrast, some studies showed that increasing oxidative stress may aid the elimination of cancer.13 Type, stage, oxygen dependence, metastasis, and angiogenesis status under hypoxia are among the determinants of the modulation of cancer cell viability by oxidative stress..$^{14}$ Therefore, targeting oxidative stress has a great potential in cancer therapy. Treatment of cancer cells with antioxidants or oxidative stress inducing agents have been widely examined in different studies. In literature, a wide range of antioxidant compounds, such as $\mathrm{N}$-acetyl cysteine, ${ }^{15}$ vitamin $\mathrm{E},{ }^{16}$ epigallocatechin gallate, ${ }^{17}$ vitamin $\mathrm{C}_{1}^{18}$ and curcumin $^{19}$ have been examined for their potential effects in cancer prevention. Antioxidants, including ascorbic acid, naringenin, and curcumin, have been examined to induce apoptosis in $\mathrm{K} 562$ chronic myeloid leukemia (CML) and HL60 acute myeloid leukemia cells. ${ }^{20-22}$ In addition to the aboved mentioned antioxidant compounds, resveratrol has been shown to inhibit proliferation, migration, and invasion of U266 multiple myeloma cells; ${ }^{23}$ however, quercetin (an antioxidant and antiinflammatory compound) was found to inhibit RPMI8226 multiple myeloma cell proliferation by inducing cell cycle arrest and apoptosis. ${ }^{24}$

Based on these findings, we aimed to analyze the effects of a known antioxidant and antiinflammatory agent (probucol) on viability of K562S and K562R CML cells, U937 histiocytic lymphoma cells, HL60 acute myeloid leukemia cells, U266 multiple myeloma cells, and L929 fibroblast cells.

\section{MATERIALS AND METHODS}

\section{Cell culture}

Human multiple myeloma cell lines [H929, U266, and RPMI8226 multiple myeloma; human CML (K562), human histiocytic lymphoma (U937), human acute myeloid leukemia (HL60), and mouse fibroblast (L929)] were cultured in RPMI-1640 (Sigma) cell culture medium including: $10 \%$ heat inactivated fetal bovine serum, L-glutamine ( $2 \mathrm{mmol} / \mathrm{L}), 100 \mu / \mathrm{mL}$ penicillin, and 100 $\mu \mathrm{g} / \mathrm{mL}$ streptomycin. Cells were incubated at $37^{\circ} \mathrm{C}, 5 \% \mathrm{CO}_{2}$, and 95\% humidity. At $80 \%$ confluence, adherent L929 cells were passaged with trypsinization.

\section{Imatinib resistant $K 562$ cell line}

$\mathrm{K} 562 \mathrm{R}$ cells, which are resistant to $5 \mu \mathrm{M}$ imatinib, were used in our experiments. $0.6 \mu \mathrm{M}$ imatinib resistant cells were kindly provided by Prof. Carlo Gambacorti-Passerini from University of Milano-Bicocca, Monza, Italy. The Imatinib resistant cells were increased to $5 \mu \mathrm{M}$ by incubating the cells with increasing concentration of imatinib at time intervals. ${ }^{25}$

\section{Cell viability}

3-(4,5-dimethylthiazol-2-yl)-2,5-diphenyltetrazolium bromide (MTT) assay was conducted to test the effect of probucol on the various human cancer cell lines and mouse fibroblast cells. For this purpose, cells $(20,000$ cells/well) were seeded onto 96-well plates. $20 \mathrm{mM}$ stock solution of probucol was pepared by dissolving probucol in dimethyl sulfoxide (DMSO) and further dilutions were prepared with culture medium. Maximum concentration of probucol applied to cells was $10 \mu \mathrm{M}$, due to low solubility of the compound at higher concentrations. H929, U266, RPMI8226, U937, and HL60 cells were treated with 0.1-10 $\mu \mathrm{M}$ probucol for $72 \mathrm{~h}$ at $37^{\circ} \mathrm{C}$. Control cells were incubated with the same concentration of DMSO as the probucol-treated cells and the DMSO concentration never exceeded $0.5 \%$. For each cell line, the same protocol was followed. K562S (imatinib sensitive) and K562 R (imatinib resistant) cells were treated with probucol 0.1-10 $\mu \mathrm{M}$ ), imatinib, and imatinib/probucol combination for $72 \mathrm{~h}$. Imatinib concentrations used for K562S and K562R cells were $0.5 \mu \mathrm{M}$ and $20 \mu \mathrm{M}$, respectively. Since imatinib is a first line therapeutic option for CML, we determined its single effect or combination effect with probucol. The effect of probucol was also detemined in non-cancerous L929 fibroblast cell line. After proper incubation, MTT solution $(5 \mathrm{mg} / \mathrm{mL}$ ) was prepared with phosphate buffer saline and cells were incubated with MTT solution for a period of four hours. Insoluble formazan crystals were dissolved by $\mathrm{SDS}-\mathrm{HCl}$ solution. Absorbance was measured at $550 \mathrm{~nm}$ using a microplate reader (Molecular Devices-Spectra Max spectrophotometer, Sunnyvale, CA, USA).

\section{Statistical anaylsis}

One-way analysis of variance with Tukey post hoc test was performed with StatistiXL Software (Nedlands, Western Australia, 6009). Data were presented as mean \pm standard deviation. $P$ values less than 0.05 was considered statistically significant.

\section{RESULTS}

According to our experiments, probucol significantly decreased the viability of $\mathrm{H} 929$ and RPMI8226 cells at the concentrations of $0.5-10 \mu \mathrm{M}$ and 5-10 $\mu \mathrm{M}$, respectively. However, we did not 
observe any antiproliferative effect on the other cell lines (Figure 1).

In our previous study, we administered $0.5 \mu \mathrm{M}$ and $20 \mu \mathrm{M}$ imatinib to K562S and K562 R cells, respectively, which are the known cytotoxic concentrations of imatinib in these cells. Treatment with imatinib alone significantly decreased the viability of $\mathrm{K} 562 \mathrm{~S}$ and $\mathrm{K} 562 \mathrm{R}$ cells to $36.92 \pm 3.44 \%$ and $48.02 \pm 1.55 \%$, respectively ( $p<0.001$ ). On the other hand, probucol did not exhibit any antiproliferative effect on both cell lines either as a single agent or in combination with imatinib (Figure 2 and 3 ).

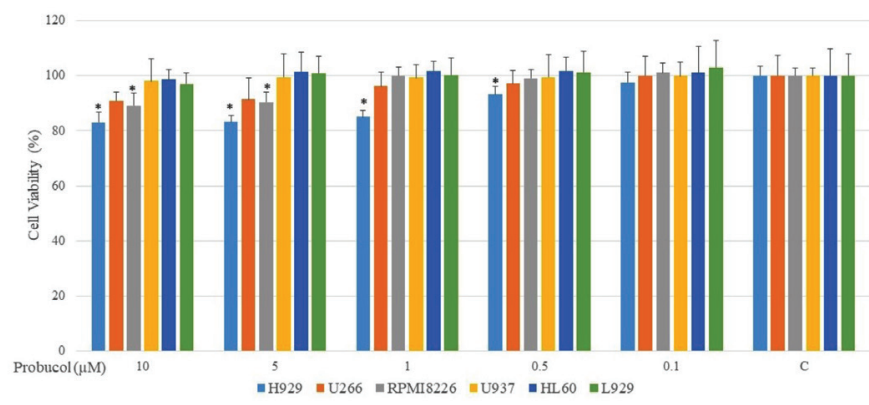

Figure 1. Human multiple myeloma (H929, U266, and RPMI8226), human histiocytic lymphoma (U937), human acute myeloid leukemia (HL60), and mouse fibroblast cell lines (L929) were treated with 0.1-10 $\mu \mathrm{M}$ probucol and cell viability was determined by MTT assay. *: p<0.05 indicates significant differences between control and probucol-treated groups. Probucol significantly decreased the cell viability of $\mathrm{H} 929$ and RPMI8226 at the concentrations of $0.5-10 \mu \mathrm{M}$ and $5-10 \mu \mathrm{M}$, respectively, MTT: 3-(4,5-dimethylthiazol-2-yl)-2,5-diphenyltetrazolium bromide

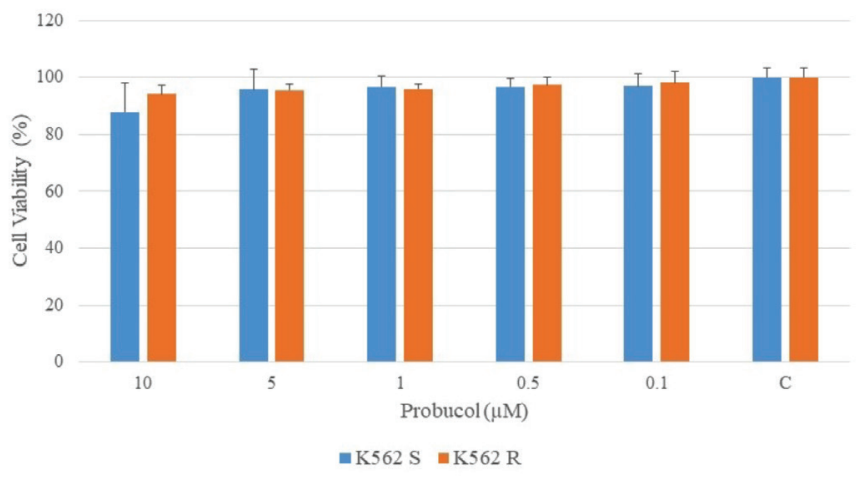

Figure 2. Imatinib-sensitive and -resistant human chronic myeloid leukemia cell lines (K562S and K562R) were treated with probucol (0.1-10 $\mu \mathrm{M})$. Cell viability was tested by MTT assay. Probucol had no significant effect on the cell viability. MTT: 3-(4,5-dimethylthiazol-2-yl)-2,5-diphenyltetrazolium bromide

\section{DISCUSSION}

In literature, various studies have investigated the efficacy of probucol treatment in cancer. In one of these studies, directed nanoassembly formulation of probucol was shown to suppress lung metastasis of breast cancer ${ }^{26}$ and, in another study, it inhibited benzopyrene-induced lung tumorigenesis. ${ }^{27}$ In

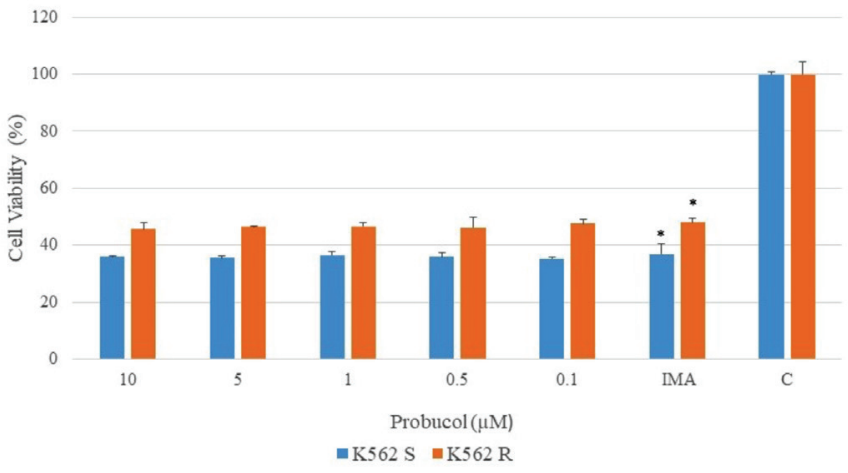

Figure 3. Imatinib-sensitive and -resistant human chronic myeloid leukemia cell lines (K562S and K562R) were treated with probucol (0.1-10 $\mu \mathrm{M})$, imatinib $(0.5 \mu \mathrm{M}$ for $\mathrm{K} 562 \mathrm{~S}$ cells, $20 \mu \mathrm{M}$ for $\mathrm{K} 562 \mathrm{R}$ cells), or probucol/ imatinib combination. Imatinib treatment significantly decreased the viability of both K562S and K562R cells. ${ }^{*} p<0.05$ indicates significant differences between control and imatinib-treated group. Viability of cells treated with imatinib and probucol also reduced when compared to the control cells. No significant difference was found between imatinib and imatinib/probucol combination treatment in both $\mathrm{K} 562 \mathrm{~S}$ and K562R cells. IMA: Imatinib

addition, probucol was reported to exhibit its antiproliferative effects via inhibition of cell cycle progression and inactivation of $\mathrm{NF}-\kappa \mathrm{B}$ and mitogen-activated protein kinase pathways in human ovarian cancer cells. ${ }^{28}$ Probucol was also reported to exert chemopreventive effect in kidney cancer ${ }^{29}$ and probucol treatment of $\kappa \mathrm{B}$ cell xenografts in mice showed a significant anticancer effect via antiangiogenic- and apoptosis-inducing mechanisms. ${ }^{30}$ To the best of our knowledge, this is the first study investigating the effects of probucol on K562S and K562R CML cells; U266, H929, and RPMI8226 multiple myeloma cells, and L929 fibroblast cells. In contrast to studies that reported a reduction of cancer cell proliferation by probucol treatment, we did not observe any potent inhibition of cell viability at 0.1-10 $\mu \mathrm{M}$ probucol treatment for all the cell lines investigated. Probucol treatment significantly inhibited the viability of $\mathrm{H} 929$ and RPMI8226 multiple myeloma cell lines at the concentrations of 0.5-10 $\mu \mathrm{M}$ and 5-10 $\mu \mathrm{M}$, respectively. However, the percentage viability in these cell lines was higher than $80 \%$ following probucol treatment, since $50 \%$ higher viability inhibition could not be achieved at the applied concentrations of probucol. According to our results, probucol had no significant effect on viability of U937 cells. In literature, probucol has been tested on U937 cells. However, most studies aimed to reveal its effects on atherosclerosis. ${ }^{31}$ In parallel to our study, one of these studies reported that the viability of U937 cells was greater than $90 \%$ followng incubation with $5 \mu \mathrm{M}$ probucol. ${ }^{32}$

\section{CONCLUSION}

Our results collectively showed that probucol was not effective in inducing cell death as a single agent in U937 histiocytic lymphoma cells, HL60 acute myeloid leukemia cells, and U266 multiple myeloma cells. Although probucol significantly inhibited H929 and RPMI8226 cell proliferation at particular doses, its effects were not potent. Probucol combined with imatinib did not alter the viability of K562S and K562R cells, 
thus showing its ineffectiveness as a combinatorial therapeutic agent in $\mathrm{CML}$.

\section{ACKNOWLEDGEMENTS}

This study was supported by Scientific Research Projects (BAP) of Ankara University (16L0237007).

Conflicts of interest: No conflict of interest was declared by the authors. The authors alone are responsible for the content and writing of the paper.

\section{REFERENCES}

1. Heel RC, RN Brogden, TM Speight, GS Avery. Probucol: A review of its pharmacological properties and therapeutic use in patients with hypercholesterolaemia. Drugs. 1978;15:409-428.

2. Buckley MM, KL Goa, AH Price, RN Brogden. Probucol. A reappraisal of its pharmacological properties and therapeutic use in hypercholesterolaemia. Drugs. 1989;37:761-800.

3. Parthasarathy S, SG Young, JL Witztum, RC Pittman, D Steinberg. Probucol inhibits oxidative modification of low density lipoprotein. The Journal of clinical investigation. 1986;77:641-644.

4. Yamashita S, D Masuda, Y Matsuzawa. Did we abandon probucol too soon? Current opinion in lipidology.2015;26:304-316.

5. Takechi R, MM Pallebage-Gamarallage, V Lam, C Giles, JC Mamo. Longterm probucol therapy continues to suppress markers of neurovascular inflammation in a dietary induced model of cerebral capillary dysfunction. Lipids in health and disease. 2014;13:91.

6. Keyamura Y, C Nagano, M Kohashi, M Niimi, M Nozako, T Koyama, R Yasufuku, A Imaizumi, $\mathrm{H}$ Itabe, $\mathrm{T}$ Yoshikawa. Add-on effect of probucol in atherosclerotic, cholesterol-fed rabbits treated with atorvastatin. PloS one. 2014;9:e96929.

7. Mamo JC, V Lam, E Brook, A Mooranian, H Al-Salami, N Fimognari, M Nesbit, R Takechi. Probucol prevents blood-brain barrier dysfunction and cognitive decline in mice maintained on pro-diabetic diet. Diabetes \& vascular disease research. 2019;16:87-97.

8. Ribeiro RP, EL Moreira, DB Santos, D Colle, AA Dos Santos, KC Peres, CP Figueiredo, M Farina. Probucol affords neuroprotection in a 6-OHDA mouse model of Parkinson's disease. Neurochemical Research. 2013;38:660-668.

9. Colle D, Santos DB, Moreira EL, Hartwig JM, dos Santos AA, Zimmermann LT, Hort MA, Farina M. Probucol increases striatal glutathione peroxidase activity and protects against 3-nitropropionic acid-induced pro-oxidative damage in rats. PLoS One. 2013;14;8:e67658.

10. Mooranian A, Zamani N, Luna G, Al-Sallami H, Mikov M, Goločorbin-Kon S, Stojanovic G, Arfuso F, Kovacevic B, Al-Salami H. Bile acid-polymerprobucol microparticles: protective effect on pancreatic $\beta$-cells and decrease in type 1 diabetes development in a murine model. Pharm Dev Technol. 2019;24:1272-1277.

11. Zucoloto AZ, Manchope MF, Borghi SM, Dos Santos TS, Fattori V, Badaro-Garcia S, Camilios-Neto D, Casagrande R, Verri WA Jr. Probucol Ameliorates Complete Freund's Adjuvant-Induced Hyperalgesia by Targeting Peripheral and Spinal Cord Inflammation. Inflammation. 2019;42:1474-1490.

12. Snezhkina AV, Kudryavtseva AV, Kardymon OL, Savvateeva MV, Melnikova NV, Krasnov GS, Dmitriev AA. ROS Generation and Antioxidant
Defense Systems in Normal and Malignant Cells. Oxid Med Cell Longev. 2019;2019:6175804.

13. Hanikoglu A, Ozben H, Hanikoglu F, Ozben T. Hybrid Compounds \& Oxidative Stress Induced Apoptosis in Cancer Therapy. Curr Med Chem. 2020;27:2118-2132.

14. Udensi UK, Tchounwou PB. Dual effect of oxidative stress on leukemia cancer induction and treatment. J Exp Clin Cancer Res. 2014;33:106.

15. Agarwal A, Muñoz-Nájar U, Klueh U, Shih SC, Claffey KP. N-acetylcysteine promotes angiostatin production and vascular collapse in an orthotopic model of breast cancer. Am J Pathol. 2004;164:1683-1696.

16. Fontana F, Moretti RM, Raimondi M, Marzagalli M, Beretta G, Procacci P, Sartori P, Montagnani Marelli M, Limonta P. $\delta$-Tocotrienol induces apoptosis, involving endoplasmic reticulum stress and autophagy, and paraptosis in prostate cancer cells. Cell Prolif. 2019;52:e12576.

17. Zan $L, C h e n Q$, Zhang L, Li X. Epigallocatechin gallate (EGCG) suppresses growth and tumorigenicity in breast cancer cells by downregulation of miR-25. Bioengineered. 2019;10:374-382.

18. Zeng $L H$, Wang QM, Feng LY, Ke YD, Xu QZ, Wei AY, Zhang C, Ying RB. High-dose vitamin $C$ suppresses the invasion and metastasis of breast cancer cells via inhibiting epithelial-mesenchymal transition. Onco Targets Ther. 2019;12:7405-7413.

19. Sun C, Zhang S, Liu C, Liu X. Curcumin Promoted miR-34a Expression and Suppressed Proliferation of Gastric Cancer Cells. Cancer Biother Radiopharm. 2019;34:634-641.

20. Sarkar R, Mukherjee A, Mukherjee S, Biswas R, Biswas J, Roy M. Curcumin augments the efficacy of antitumor drugs used in leukemia by modulation of heat shock proteins via HDAC6. J Environ Pathol Toxicol Oncol. 2014;33:247-263.

21. Mastrangelo D, Massai L, Lo Coco F, Noguera NI, Borgia L, Fioritoni G, Berardi A, lacone A, Muscettola M, Pelosi E, Castelli G, Testa U, Di Pisa F, Grasso $G$. Cytotoxic effects of high concentrations of sodium ascorbate on human myeloid cell lines. Ann Hematol. 2015;9:1807-1816.

22. Li RF, Feng YQ, Chen JH, Ge LT, Xiao SY, Zuo XL. Naringenin suppresses K562 human leukemia cell proliferation and ameliorates Adriamycininduced oxidative damage in polymorphonuclear leukocytes. Exp Ther Med. 2015;9:697-706.

23. Geng W, Guo X, Zhang L, Ma Y, Wang L, Liu Z, Ji H, Xiong Y. Resveratrol inhibits proliferation, migration and invasion of multiple myeloma cells via NEAT1-mediated Wnt/beta-catenin signaling pathway. Biomed Pharmacother. 2018;107:484-494.

24. Najibi A, Heidari R, Zarifi J, Jamshidzadeh A, Firoozabadi N, Niknahad $\mathrm{H}$. Evaluating the Role of Drug Metabolism and Reactive Intermediates in Trazodone-Induced Cytotoxicity toward Freshly-Isolated Rat Hepatocytes. Drug Res (Stuttg). 2016;66:592-596.

25. Hekmatshoar Y, Ozkan T, Altinok Gunes B, Bozkurt S, Karadag A, Karabay $A Z$, Sunguroglu A. Characterization of imatinib-resistant K562 cell line displaying resistance mechanisms. Cell Mol Biol (Noisy-le-Grand). 2018;64:23-30.

26. Zhang Z, H Cao, S Jiang, Z Liu, X He, H Yu, Y Li. Nanoassembly of probucol enables novel therapeutic efficacy in the suppression of lung metastasis of breast cancer. Small (Weinheim an der Bergstrasse, Germany). 2014;10:4735-4745.

27. Zarkovic M, Qin X, Nakatsuru Y, Zhang S, Yamazaki Y, Oda H, Ishikawa T, Ishikawa T. Inhibitory effect of probucol on benzo[a]pyrene induced lung tumorigenesis. Carcinogenesis. 1995;16:2599-2601. 
28. Chuang LY, Guh JY, Ye YL, Lee YH, Huang JS. Effects of probucol on cell proliferation in human ovarian cancer cells. Toxicol Res (Camb). 2016;5:331-339

29. Iqbal M, Okazaki Y, Okada S. Probucol modulates iron nitrilotriacetate (Fe-NTA)-dependent renal carcinogenesis and hyperproliferative response: diminution of oxidative stress. Mol Cell Biochem. 2007;304:6169.

30. Nishimura G, Yanoma Y, Mizuno H, Kawakami, Tsukuda M. An antioxidant, probucol, induces anti-angiogenesis and apoptosis in athymic nude mouse xenografted human head and neck squamous carcinoma cells. Jpn J Cancer Res. 1999;90:1224-1230.
31. Kaneko M, Hayashi J, Saito I, Miyasaka N. Probucol downregulates E-selectin expression on cultured human vascular endothelial cells. Arterioscler Thromb Vasc Biol. 1996;16:1047-1051.

32. Chen JW, Chen YH, Lin FY, Chen YL, Lin SJ. Ginkgo biloba extract inhibits tumor necrosis factor- $\alpha$-induced reactive oxygen species generation, transcription factor activation, and cell adhesion molecule expression in human aortic endothelial cells. Arterioscler Thromb Vasc Biol. 2003;23:1559-1566. 